\title{
A Survey of Trypanosome Species Circulating In Pigs In Three Selected Local Government District of Enugu State, Nigeria
}

\author{
Omeje, J.N. ${ }^{1}$ and Akinbobola J.S. ${ }^{2}$ \\ ${ }^{1}$ Department of Veterinary Medicine, University of Abuja \\ ${ }^{2}$ Veterinary Teaching Hospital, University of Abuja
}

Accepted January, 2019 and Published February, 2019

\begin{abstract}
A cross sectional survey of trypanosomosis of pigs was carried out in three randomly selected Local Government Areas (Nsukka, Udenu and Igbo Eze South) out of the six local government areas in Enugu North Senatorial Zone. Blood samples were randomly collected from a total of 1800 pigsfrom abattoirs and farms and were examined for trypanosomes parasites using standard parasitological methods: wet film, buffy coat and Giemsa-stained thin smear preparations. A total of 93 (5.2\%) pigs were positive overall. Among the positive samples, Trypanosoma brucei was the predominant species (86.0\%), followed by T. congolense (13.9\%). The different relative isolation rate for Nsukka, Igbo-Eze South and Udenu Local government areas were 14 (4.7\%), 14 (4.7\%), and 19 (4.0\%) respectively in the dry season, and $17(5.7 \%), 17$ (5.7\%) and $12(6.3 \%)$ in the rainy season respectively. The trypanosome prevalence in males from Nsukka, Igbo-Eze South and Udenu local governments were 6.5\%, 6.2\% and 4.2\% respectively, while report in female were $3.8 \%, 4.1 \%$ and $5.9 \%$ in the three local governments respectively. There was no significant variations $(p<0.05)$ with seasons, sex and age groups. It was therefore concluded that porcine trypanosomosis is still endemic in Enugu North Senatorial Zone withT. bruceibeing the most incriminated as the cause of the disease in the zone.
\end{abstract}

Key words: Prevalence, Trypanosomosis, Porcine, Seasonal, Enugu North

\footnotetext{
*Corresponding Author:

E Mail: omeje.nduka@uniabuja.edu.ng
}

Tel: +2347054434414 


\section{INTRODUCTION}

Pigs are considered as one of the principal livestock, and their good health, survival and development are necessary to ameliorate the increasing demand on the supply of animal protein. Trypanosomosis constitute a major constraint to pig production particularly in the tropics where it has high potential to boost meat production [1,2].Demand for pork in Enugu North Senatorial area is high and there are no cultural or religious barrier affecting its consumption. Some of the factors that affect the prevalence of trypanosomosis in Nigeria include animal breed, type of management, season of the year and the type of vegetation [3]. Earlier research findings indicated a high prevalence of trypanosomosis among pigs kept in some tsetse infested and trypanosomosis endemic areas of Nigeria. In similar studies, [4] reported a prevalence of $30.7 \%$ in 150 local and exotic breeds of pigs in Nsukka area while[5] recorded an infection rate of $26.8 \%$ in 1,954 (abattoir slaughtered and field market) pigs in middle belt zone of Nigeria. In addition, [6] also reported $4 \%$ prevalence in 300 pigs screened for trypanosome in Nsukka abattoir.

Porcine trypanosomosis is not only of economic importance for pig rearing but also has public health significance. This is because pigs act as carriers of Trypanosome brucei gambiense and Trypanosome brucei rhodesiense and thus act as reservoir of trypanosome species that can infect man $[7,8]$. The unfolding importance of porcine trypanosomosis has called for regular monitoring of the pig stocks in order to determine the prevalence of trypanosome infection, enhance timely drug intervention and avoid huge economic losses [9].
This survey was conducted to determine the prevalence of trypanosome species in pigs in both abattoir-slaughtered pigs and piggery farms in Enugu North Senatorial zone of Enugu state, Nigeria.

\section{MATERIALSAND METHODS}

\section{Study Area}

The study was carried out in North Senatorial zone of Enugu State, Southeastern Nigeria. It is located in the derived savannah ecological zone at latitude $6^{\circ} 51^{\prime} 24^{\circ} \mathrm{N}$ and longitude $7^{\circ} 23^{\prime} 45^{\circ} \mathrm{E}$ at an elevation of $1,810 \mathrm{ft}(550 \mathrm{~m})$ above sea level [10].The area experiences two discrete seasons; rainy and dry seasons with mean annual rain fall of $1500-2100 \mathrm{~mm}$ [11]. The mean temperature varies between $16.6^{\circ} \mathrm{c}$ $37.6^{\circ} \mathrm{c}$. The zone has six local government areas (LGA). The indigenous people are involved in agriculture, basically crop and livestock farming activities [12].

\section{Sample population}

Purposive non-probability method was used to select three (3) LGAs within the Senatorial Zone. Samples were selected through simple random technique, and in each of the LGA, three (3) communities were selected for sampling, while purposive non-probability method was used to select farms for sampling. In each of the selected LGAs, one abattoir with the highest slaughter capacity was selected for sampling.

The farms visited practiced intensive management of the herd. The pigs were raised on concrete floors and mosquito nets put in place to wade off insects and flies. The herd structure comprised piglets, growers, gilts, 
sows and boars; and in most of the farms visited the pigs were separated by age and weight. The pig farms comprised of genetically improved breeds (Large White, Landrace, Duroc and their crosses). None of the sampled farms had indigenous breed of pigs. During sampling; seasons (dry and wet), sex and age were recorded. The age was categorized into four ( 0 12 months, 13-24 months, 25- 36 months and greater than 36 months)groups.

\section{Determination of sample size}

For this study, three hundred (300) pigs were selected from each of the local government for each of the seasons. With an estimated prevalence of $20 \%$, confidence interval of $95 \%$ and $5 \%$ precision: sample size was calculated according to the formula given by[13].

\section{Collection of blood samples from Abattoirs}

Systematic random sampling technique was used to select every second pigs slaughtered on the day of sampling. For each of the seasons, a total of 900 blood samples were collected from the 3 abattoirs sampled within 3 LGAs in the zone for the period of the study.

Abattoir blood samples were collected in ethylenediaminetetraacetic acid (EDTA) contained sample bottles at slaughter from the severed jugular

\section{Collection of blood samples from farms}

Animals were randomly selected from each farm as described by [14] and bled from the marginal ear vein and blood was collected into an anti-coagulant ethylenediaminetetracetic acid (EDTA) tubes. A total of 900 samples were collected from the 3 LGA for each of the seasons. All the samples were kept on ice and taken to the laboratory for examination.

\section{Packed cell volume}

The microhaematocrit centrifuge technique was used for the determination of PCV [15]. PCV was read using the PCV reader. The result was expressed in percentage (\%).

\section{Determination of parasitaemia}

\section{Wet mount}

Using standard laboratory procedure, a drop of blood was made on a slide, covered with a cover slip and viewed under the microscope using $\times 40$ objective for flagellated movement of the Trypanosomespp.

\section{Buffycoat}

The buffy- coat used was obtained after the PCV reading. The capillary tube was cut a few millimeters bellow the buffy-coat level. The buffy-coat and some plasma were gently expressed on the slide, carefully mixed and covered with a cover slip and viewed under a microscope using $x 40$ objective for trypanosomes $[16,17]$.The species of trypanosomes were identified by their morphological characteristics on Giemsastained thin blood film preparations [18].

Statistical analysis: Descriptive statistics, chisquare tests were used to express results and analysis of variables using SPSS (version 19).

\section{RESULTS}

The result of the survey shows that the overall prevalence of porcine trypanosomosis in Enugu North Senatorial Zone is $5.2 \%$. The distribution of the trypanosome species demonstrated that $T$. brucei was the most prevalent with $84.9 \%$, while $T$. congolense was $15.1 \%$. No record of mixed infection was seen in the sampled pigs (Table 1).The study also revealed a dry season 
trypanosome prevalence of $4.7 \%, 4.7 \%$, and $4.0 \%$ while it was $5.7 \%, 5.7 \%$ and $6.3 \%$ in wet season in Nsukka, Igbo-Eze South and Udenu LGAs respectively (Table 2). There were no statistical differences $(p>0.05)$ between prevalence and seasons of the year.

The results of survey showed that the prevalenceof trypanosome infection in male were $6.5 \%, 6.2 \%$ and $4.2 \%$ respectively, while that of the female were $3.8 \%, 4.1 \%$ and $5.9 \%$ for Nsukka, Igbo-Eze South and Udenu (Table 3). There was however, no statistical significant differences $(p>0.05)$ between prevalence and sex of the animals. The results of age group prevalence indicate that there were no statistical differences when the different age groups were compared with the prevalence of infection (Table 4). The Mean PCV (\%) for the trypanosome infected pigs slaughtered at the abattoir were $25.3 \pm 4.5,24.8 \pm 4.6$ and $23.5 \pm 3.6$ for Nsukka, Igbo Eze and Udenu LGA, respectively, while, it was $35.4 \pm 6.2,35.5 \pm 7.0$ and $35.4 \pm 5.2$ for uninfected pigs.Similarly, the Mean PCV for infected pigs sampled from the piggery farms were $26.7 \pm 3.6,24.3 \pm 3.4$ and 21.1 \pm 3.9 for Nsukka, Igbo-Eze and Udenu LGAs, respectively, while it was $35.7 \pm 4.8$, $35.0 \pm 5.2$ and $34.2 \pm 6.0$ for uninfected pigs. There was significant difference $(p<0.05)$ in the Mean PCV between the infected and noninfected pigs (Table 5).

Table 1: Prevalence of Trypanosome spp in pigs in LGA of Enugu North Senatorial Zone

\begin{tabular}{|c|c|c|c|c|c|c|}
\hline \multirow[t]{2}{*}{ LGA } & \multirow{2}{*}{$\begin{array}{l}\text { No of animal sampled in } \\
\text { both dry and wet season }\end{array}$} & \multirow[t]{2}{*}{ No positive } & \multirow[t]{2}{*}{ Prevalence (\%) } & \multicolumn{3}{|c|}{ Species of trypanosomes } \\
\hline & & & & T. brucei & T. congo & Mixed \\
\hline Nsukka & 600 & 31 & 5.2 & 25 & 6 & 0 \\
\hline Igboeze & 600 & 31 & 5.2 & 29 & 3 & $\mathbf{0}$ \\
\hline Udenu & 600 & 31 & 5.2 & 26 & 4 & 0 \\
\hline Total & 1800 & 93 & 5.2 & 80 & 13 & 0 \\
\hline
\end{tabular}

Table 2: Seasonal prevalence of Trypanosome spp in pigs in LGAs ofEnugu North Senatorial Zone

\begin{tabular}{lllll}
\hline LGA & Seasons & No sampled & No positive & Prevalence (\%) \\
\hline Nsukka & Dry & 300 & 14 & 4.7 \\
& Wet & 300 & 17 & 5.7 \\
\hline Igboeze & Dry & 300 & 14 & 4.7 \\
& Wet & 300 & 17 & 5.7 \\
\hline Udenu & Dry & 300 & 12 & 4.0 \\
& Wet & 300 & 19 & 6.3 \\
\hline$\chi^{2}$ value $=2.161, \mathrm{df}=5$, P-value $=0.826$ & & \\
\hline
\end{tabular}

$\chi^{2}$ value $=2.161, \mathrm{df}=5, \mathrm{P}$-value $=0.826$ 
Table 3: Sex prevalence of Trypanosome spp in pigs in LGAs of Enugu North Senatorial Zone

\begin{tabular}{|c|c|c|c|c|c|c|c|}
\hline \multirow[t]{2}{*}{ LGA } & \multirow[t]{2}{*}{ Sample type } & \multirow[t]{2}{*}{ No sampled } & \multirow{2}{*}{\multicolumn{2}{|c|}{ Sex (count) }} & & & \multirow[t]{2}{*}{ Positives (\%) } \\
\hline & & & & & Sex (Pre & ce) & \\
\hline & & & Male & Female & Male & Female & \\
\hline \multirow[t]{2}{*}{ Nsukka } & Abattoir & 300 & 203 & 97 & $10(4.9 \%)$ & $6(6.2 \%)$ & $16(5.3 \%)$ \\
\hline & Farm & 300 & 107 & 193 & $10(9.3 \%)$ & $5(2.6 \%)$ & $15(5.0 \%)$ \\
\hline \multirow[t]{2}{*}{ Igboeze } & Abattoir & 300 & 174 & 126 & $15(8.6 \%)$ & $5(4.0 \%)$ & $20(6.7 \%)$ \\
\hline & Farm & 300 & 112 & 188 & $3(2.7 \%)$ & $8(4.3 \%)$ & $11(3.7 \%)$ \\
\hline \multirow[t]{2}{*}{ Udenu } & Abattoir & 300 & 176 & 124 & $9(5.1 \%)$ & $9(7.3 \%)$ & $18(6.0 \%)$ \\
\hline & Farm & 300 & 85 & 215 & $2(2.4 \%)$ & $11(5.1 \%)$ & $13(4.3 \%)$ \\
\hline TOTAL & & 1800 & 857 & 943 & $49(5.7 \%)$ & $44(4.7 \%)$ & $93(5.2 \%)$ \\
\hline
\end{tabular}

$\chi^{2}$ value $=1.02, \mathrm{df}=1, \mathrm{p}$-value $=0.29$

Table 4: Age prevalence of Trypanosome spp in pigs in LGAs in Enugu North Senatorial Zone

\begin{tabular}{|c|c|c|c|c|c|c|c|c|c|c|c|}
\hline \multirow[t]{3}{*}{ LGA } & \multirow[t]{3}{*}{ Source } & \multirow[t]{3}{*}{ Samples (n) } & \multicolumn{8}{|c|}{ Age groups (months) } & \multirow[t]{3}{*}{ Positives (\%) } \\
\hline & & & \multicolumn{4}{|c|}{ Samples (n) } & \multicolumn{4}{|c|}{ Positives (\%) } & \\
\hline & & & $0-12$ & $13-24$ & $25-36$ & $>37$ & $0-12$ & $13-24$ & $25-36$ & $>37$ & \\
\hline \multirow[t]{2}{*}{ Nsukka } & Abattoir & 300 & 30 & 130 & 115 & 25 & $1(3.3 \%)$ & $9(6.9 \%)$ & $5(4.3 \%)$ & $1(4.0 \%)$ & $16(5.3 \%)$ \\
\hline & Farm & 300 & 124 & 96 & 62 & 18 & $8(6.5 \%)$ & $5(5.2 \%)$ & $2(3.2 \%)$ & $0(0.0)$ & $15(5.0 \%)$ \\
\hline \multirow[t]{2}{*}{ Igboeze } & Abattoir & 300 & 63 & 139 & 89 & 9 & $1(1.6 \%)$ & $13(9.4 \%)$ & $6(6.7 \%)$ & $0(0.0)$ & $20(6.7 \%)$ \\
\hline & Farm & 300 & 80 & 125 & 88 & 7 & $3(3.8 \%)$ & $4(3.2 \%)$ & $3(3.4 \%)$ & $1(14.3 \%)$ & $11(3.7 \%)$ \\
\hline \multirow[t]{2}{*}{ Udenu } & Abattoir & 300 & 6 & 157 & 130 & 7 & $0(0.0)$ & $9(5.7 \%)$ & $9(6.9 \%)$ & $O(0.0)$ & $18(6.0 \%)$ \\
\hline & Farm & 300 & 103 & 122 & 72 & 3 & $4(3.9 \%)$ & $5(4.1 \%)$ & $4(5.6 \%)$ & $0(0.0)$ & $13(4.3 \%)$ \\
\hline
\end{tabular}

$\chi^{2}$ value $=2.28, \mathrm{df}=3, \mathrm{p}$-value $=0.50$ 
Table 5: Mean \pm SEM PCV (\%) of parasitaemia and aparasitaemic pigs in Enugu North Senatorial Zone

\begin{tabular}{llllll}
\hline LGA & & Infected & Uninfected & t-value & p-value \\
\hline Nsukka & Abattoir & $25.3 \pm 4.5$ & $35.4 \pm 6.2$ & 6.4 & 0.0000 \\
& Farm & $26.7 \pm 3.6$ & $35.7 \pm 4.8$ & 7.9 & 0.0000 \\
Igboeze & Abattoir & $24.8 \pm 4.6$ & $35.5 \pm 6.9$ & 6.8 & 0.0000 \\
& Farm & $24.3 \pm 3.4$ & $35.1 \pm 5.2$ & 6.8 & 0.0000 \\
& Abattoir & $23.5 \pm 3.6$ & $35.4 \pm 5.2$ & 9.7 & 0.0000 \\
& Farm & $21.1 \pm 4.0$ & $34.2 \pm 6.0$ & 7.9 & 0.0000 \\
\hline
\end{tabular}

$\mathbf{p}<0.05$ shows significant difference

\section{DISCUSSION}

The results of this study further confirm that trypanosomosis due mainly to T. brucei brucei still constitutes an important disease of pigs in Enugu North Senatorial Zone. This is in agreement with earlier report of $[4,6,20]$ citing T. brucei as a major cause of porcine trypanosomosis in the study area. Taking into account the limitations of the parasitological diagnostic methods and the uncontrolled use of trypanocidal drugs [17]; the true prevalence of infection may probably be substantially higher than is reported in this study.

The high prevalence observed in this study for Nsukka, Igbo-Eze South and Udenu slaughtered pigs is in agreement with the record of $4.0 \%$ prevalence rate reported by $[18]$ in pigs surveyed in Nsukka abattoir. However, the prevalence is low when compared with the findings of earlier researchers [19]. They recorded a prevalence of $57 \%$ in 56 pigs examined, while [20] reported a prevalence of $30.7 \%$ in both exotic and local breeds in the Nsukka area. Similarly, [5] in his report on abattoir slaughtered pigs and field survey of 1,954 in the middle belt area of Nigeria recorded $26.8 \%$ prevalence. The observed lower prevalence could be attributed to the improvement in the animal husbandry and veterinary services within the zone.

The result also reflects a higher infection rate of slaughtered pigs in the abattoirs compared with piggeries in the zone. Though the differences are not statistically significant the higher infection rates in the abattoir-slaughtered pigs is in agreement with the findings of [5] who reported higher infection rate among abattoir 
slaughtered pigs than farm pigs. The higher infection rate in the abattoir slaughtered pigs could be attributed to the fact that majority of the farmers prefer to sell off the chronic ailing animals for slaughter while retaining the healthier ones in the farms.

The present study also indicated significant difference between PCV of infected and noninfected pigs. The low $\mathrm{PCV}$ of the infected pigs which is indicative of anaemia is in agreement with previous findings of $[21,22]$ that anemia is one of the most persistent features of animal trypanosomosis.

It can be concluded that $T$. bruce is mainly prevalent in Enugu North Senatorial Zone. It is also an important cause of anaemia in the area that poses potential threat to the health and productivity of pigs in the area. This finding emphasizes the need for effective and integral control of the parasite and the vectors in Enugu North Senatorial Zone.

\section{Acknowledgement $\backslash$}

The authors appreciate the staff of the department of Veterinary Medicine, University of Nigeria, Nsukka

\section{REFERENCES}

1. Nwanta, J.A., Shonyinka S.V.O., Chah, K.F., Onunkwo J.O., Onyenwe I.W., Eze J.I., Iheagwam C.N., Njoka E.O., Onyema I., Ogbu K.I., Mgbegbu E.C., Nnadozie P.N., Ibe E.C and Oladimeji K.T. (2011). Production characteristics, disease prevalence and herd - health management of pigs in Southeast Nigeria. Journal of Swine Health and Production, 19(6):331-339.
2. Ngaoyo, M.O., Njiru, Z.K., Kenya, E.U., Muluvi, G.M,. Osir, E.O and Masiga D.K. (2005). Detection of trypanosomes in small ruminants and pigs in western Kenya: important reservoirs in the epidemiology of sleeping sickness? Kinetoplastid Biology and disease, 45: 1-7.

3. Waiswa, C. (2005). Porcine trypanosomiasis in Southeast Uganda: Prevalence and assessment of therapeutic effectiveness. Bulgarian Journal Veterinary Medicine, 8 (1):5968.

4. Ogunsanmi, A.O., Ikede B.O., Akpavie S.O (2000).Effects of management, season, vegetation, and breed on the prevalence of bovine trypanosomosis in South-Western Nigeria. Israel Journal of Veterinary Medicine, 55(2):273-278.

5. Omeke, B.C.O. (1994). Pig trypanosomosis: prevalence and significance in the endemic Middle Belt zone of Southern Nigeria. Revue d'Elévageet de Médécine vétérinaire des Pays tropicaux, 47:381-386.

6. Gibson, W., Mehlitz, D., Lanham, S.M and Godfrey, D.G (1978). The identification of Trypanosoma brucei gambiense in Liberian pigs and dogs by isoenzymes and by resistance to human plasma.Tropenmedizin und Parasitologie, 29:335-345

7. Waiswa, C., Olaho-Mukami, W. and Katunguka-waki S.E (2003).Domestic animals reservoirs for sleeping sickness in three endemic foci in south-eastern Uganda.Annals of Tropical Medicine and Parasitology, 97: 149-153

8. 42 
8. Onah, D.N and Uzoukwu M (1991). Porcine cerebral Trypanosome bruceibruceitrypanosomiasis. Tropical Animal Health and Production, 23:39-44.

9. National Population Commission (2010). Population Distribution by Sex, State, LGA \& Senatorial district; Federal Republic of Nigeria, 2006 Population and Housing Census: Priority Table, Volume III

10. Abonyi, F. O., Omeh C.V.O and Machebe N.S (2012). Neonatal mortality of pigs in Nsukka, south east Nigeria. African Journal of Biotechnology 11(68):1322813234

11. Thrusfield, M ( 2007). Veterinary Epidemiology, 3rd Edition. London: Blackwell Science

12. Putt, S.N.H., Shaw A.P.M., Woods A.J., Tyler L and James A.D (1987). Veterinary epidemiology and economics in Africa: A manual for use in the design and appraisal of livestock health policy.ILCA Manual 3. ILCA (International Livestock Centre for Africa), Addis Ababa, Ethiopia. Pp $130-135$.

13. Jain, N.C. (1986). Schalm's Veterinary Haematology. 4th edition. Lea and Febigir, Philadelphia

14. Paris, J., Murray M. and McOdimba, F (1982). A comparative evaluation of parasitological techniques currently available for the diagnosis of African trypanosomiasis in cattle. ActaTropica, 39:307-316.

15. Murray, M., Trail J.C.M, Turner D.A. and Wissocq, Y (1983). Livestock Productivity and trypanotolerance: Network Training Manual, International Livestock Center for Africa (Ireland ) 6: 159-165.
16. Soulsby, E.J.L (1986). Helminths, Arthropods and Protozoa of domestic animals, $8^{\text {th }}$ Edition, BalliereTindall, London. Pp 203-206.

17. Abdalla, M. A., Amel, O. B and Seham E.S. (2005). Trypanosoma vivax infection in Sudanese cattle in central Sudan. Journal of Animal and Veterinary Advances, 4(11): 945-948

18. Anene, B.M., Ifebigh A., Igwilo I.A and Umeakuana P.U. (2011). Prevalence and haemato-biochemical parameters of trypanosomes infected pigs at Nsukka, Nigeria. Comparative Clinical Pathology, 20:1518

19. Killick-Kendrick, R. and Godfrey, D.G (1963). Observations on a close association between Glossina tachynoides and domestic pigs near Nsukka, Eastern Nigeria. In Trypanosoma congolense and T. brucei infections in the pigs. Annals of Tropical Medicine and Parasitology, 57: 225-231.

20. Onah, D.N (1991). Porcine trypanosomiasis in Nigeria: Infections in local and exotic pigs in the Nsukka area of Anambra State. Tropical Animal Health and Production, 123: 141-146

21. Anosa, V.O. and Obi T.U (1980). Haematological studies on domestic animals in Nigeria: The effects of age, breed and haemoglobin type on bovine haematology and anaemia. Zentralblatt Fur VeterinariarmedizinReihe, 27: 773788.

22. Omeke, B.C.O and Ugwu D.O (1991). Pig trypanosomosis: comparative anaemia and histopathology of lymphoid organs. Revue d'Elévageet de Médécine vétérinaire des Pays tropicaux, 44: 267267. 